\title{
Policy Integration for Sustainable Development through Multilateral Environmental Agreements
}

An Empirical Analysis, 2007-2016

\author{
Dona Azizi \\ Utrecht University, The Netherlands \\ d.azizi@uu.nl \\ Frank Biermann \\ Utrecht University, The Netherlands \\ f.biermann@uu.nl \\ Rakhyun E. Kim \\ Utrecht University, The Netherlands \\ r.kim@uu.nl
}

\begin{abstract}
Over the past three decades, policy integration has become a key objective for guiding and harmonizing policies for sustainable development. Most recently, the 2015 Sustainable Development Goals have added new impetus to efforts of integrating competing objectives of environmental sustainability, social development, and economic growth, as well as of integrating issue-specific environmental policies on climate change and terrestrial and marine biodiversity. While multilateral environmental agreements are important international instruments for achieving sustainable development, there has been little focus so far on their contribution to policy integration. Covering the years from 2007 to 2016, this article presents an empirical analysis of sustainability policy integration (i.e., how multilateral environmental agreements integrate environmental, social, and economic issues in their decisions) and environmental policy integration (i.e., the outreach of multilateral environmental agreements to different environmental issue areas beyond their mandate). The analysis finds that multilateral environmental agreements have not moved toward further policy integration over the studied period. If policy and institutional coherence is a key global governance target in the post-2015 era, a concerted effort will be required to improve the extent of policy integration by multilateral environmental agreements.
\end{abstract}




\section{Keywords}

policy integration - multilateral environmental agreements - sustainable development goals - fragmentation - Global Governance

\section{Introduction}

Over the past three decades, ${ }^{1}$ the integration of policies from different areas has become a central objective of sustainability governance, nationally as well as internationally. The 2030 Agenda for Sustainable Development with the seventeen Sustainable Development Goals ${ }^{2}$ has added new impetus to the aim of integrating environmental sustainability, social development, and economic growth; that is, sustainability policy integration. Renewed emphasis has been placed as well on the integration of environmental policies; that is, environmental policy integration. ${ }^{3}$ While the Sustainable Development Goals build on the traditional "pillars" of sustainable development ${ }^{4}$ —environment, society and economy - together, they are intended to constitute one "integrated and indivisible" ${ }^{5}$ package. In that sense, the Sustainable Development Goals pose a "considerable widening of the integration challenge" 6 for institutions such as multilateral environmental agreements. ${ }^{7}$ As key international institutions for addressing global environmental issues, ${ }^{8}$ multilateral environmental agreements must play a significant role in overall policy integration. ${ }^{9}$

However, multilateral environmental agreements often operate in silos, which hinders policy integration. Also, multilateral environmental agreements are often distinct in membership and mandates, partially because they have been crafted at different times and in response to different issues by different groups of countries. ${ }^{10}$ Specialized governmental ministries often negotiate or

1 Since the "Report of the World Commission on Environment and Development: Our Common Future" 1987; and at latest "The Rio Declaration on Environment and Development" 1992.

2 UN General Assembly, Resolution A/RES/7o/1 (2015a).

3 Biermann, Kanie, and Kim 2017.

4 Sachs 2012.

5 UN General Assembly, Resolution A/RES/70/1, Preamble (2015b).

$6 \quad$ Nilsson and Persson 2017.

7 Chasek and Wagner 2012.

8 Steiner, Kimball, and Scanlon 2003.

9 UNEP/DELC 2016.

10 Keohane and Victor 2011, 19. 
implement these agreements without much concern for other ministries that are responsible for other agreements and policies. Moreover, powerful parties to these agreements may have a strategic interest in keeping issues or institutions separate, ${ }^{11}$ and international bureaucracies such as treaty secretariats are engaging in what some observe as institutional "turf wars" that prevent policy integration among and beyond multilateral environmental agreements. ${ }^{12}$

Therefore, multilateral environmental agreements are often poorly coordinated with no clear hierarchical order. Numerous treaty bodies and other institutions operate with little formal linkages with each other, and create norms and standards often independently and hardly in an integrated manner. ${ }^{13}$ Many multilateral environmental agreements thus conflict with each other, with some that are unable to adjust to and cooperate with the work of other international institutions. ${ }^{14}$ Such treaty conflicts may manifest in negative spillovers, problem shifting, or legal inconsistencies, and, hence, a system of agreements that operates at a suboptimal level. ${ }^{15}$ Therefore, researchers and policymakers alike are concerned about institutional fragmentation in earth system governance. ${ }^{16}$ And yet, despite this general understanding of the adverse consequences of the lack of sufficient institutional interlinkages or cooperative interaction, ${ }^{17}$ institutional silos and policy disintegration seem to persist.

Yet is this picture too gloomy? Little systematic knowledge is available, we argue, about the extent to which treaty bodies of multilateral environmental agreements actually seek to integrate interdependent yet institutionally fragmented environmental, social, and economic issues into their decisionmaking. ${ }^{18}$ For example, we know from a previous study that the network of multilateral environmental agreements is modular in structure. ${ }^{19}$ The observed structure conforms to the conventional organization of law with its clusters of agreements correlating highly with underlying legal semantics. ${ }^{20}$ It is unknown, however, whether the gaps between these clusters have been bridged

\footnotetext{
11 Benvenisti and Down 2007; Drezner 2009.

12 Bull, Hoft, and Sutton 2011.

13 Biermann, Davies, and van der Grijp 2009, 351.

14 Wolfrum and Matz 2011; Wiersema 2009, 287.

15 Fischer-Lescano and Teubner 2004; Kim and van Asselt 2016.

16 Fischer-Lescano and Teubner 2004, 1001-1002; Biermann 2014.

17 Chambers 2008.

18 Prost and Kingsley Clark 20o6; van Asselt, Sindico, and Mehling 2008; Chambers 2008.

19 Kim 2013.

20 Sizable and clearly distinguishable clusters include the marine environment, biodiversity, maritime safety and liability, watercourses, atmosphere, hazardous wastes, plant protection, and nuclear related. See Kim 2013.
} 
through the subsequent work of their treaty bodies such as the conferences of the parties or treaty secretariats. Often these treaty bodies are obliged to coordinate and cooperate with treaty bodies of other multilateral environmental agreements. ${ }^{21}$ But did this lead actually to more policy integration between multilateral environmental agreements?

This article seeks to address this research gap through an exploratory analysis of sustainability and environmental policy integration in a group of key multilateral environmental agreements. We map environmental, social, and economic issue areas in the decisions of multilateral environmental agreements, assess varying degrees of policy integration, and discuss implications for global governance toward sustainable development.

Normatively, we follow the framework of the Sustainable Development Goals that strive for an integrated consideration of environmental, social, and economic concerns. We define policy integration as a process through which institutions, such as multilateral environmental agreements, incorporate into their decision-making issues that stand beyond their own specialization. ${ }^{22} \mathrm{We}$ draw on previous studies on policy integration within single environmental areas, such as biodiversity $l o s s^{23}$ or climate change, ${ }^{24}$ but also on those covering a few connected environmental areas such as forests, agriculture, climate, and energy. ${ }^{25}$ We aim to contribute to the literature on policy integration in the field of sustainable development, ${ }^{26}$ focusing in particular on policy integration for the implementation of the Sustainable Development Goals. ${ }^{27}$ This study also supports ongoing efforts in improving interinstitutional cooperation ${ }^{28}$ through a greater consideration of cross-regime sensitivities. ${ }^{29}$

Covering the years from 2007 to 2016, we explored two key questions. First, to what extent have multilateral environmental agreements in their decisions tried to integrate environmental, economic, and social areas of sustainable development? Second, to what extent have multilateral environmental agree-

$21 \quad$ Kim and Bosselmann 2013.

22 See Briassoulis 2004, 11, on the argument that existing research does not align under one clear definition of policy integration in the field of sustainability governance, which leads to diverse and often unclear definitions of the objects and modes of integration.

23 Velázquez Gomar 2016.

24 Adelle and Russel 2013.

25 Hogl, Kleinschmitt, and Reyner 2016.

26 Runhaar, Driessen, and Uittenbroek 2014; Jordan and Lenschow 2010.

27 Nilsson and Persson 2017.

28 Abbott, Green, and Keohane 2013.

29 Perez 2005, 739. 
ments in their decisions tried to integrate other environmental issue areas? We draw on evidence from forty-seven multilateral environmental agreements and their decision documents, which resulted from 164 meetings of their main decision-making bodies.

The article is structured as follows. After this introduction, we elaborate on the methodology and how we designed and implemented the empirical analysis. We then discuss results in two sections. First, we analyze to what extent the forty-seven multilateral environmental agreements have integrated environmental, social, and economic issues in their decisions over time. Second, we study the integration of different environmental issue areas in decisions by these forty-seven multilateral environmental agreements over time. The results are followed by a discussion where we reflect on the results in light of the Sustainable Development Goals and the draft Global Pact for the Environment. Finally, we summarize the results and provide suggestions for future research.

\section{Research Design and Methods}

To analyze policy integration of multilateral environmental agreements, we conducted a quantitative keyword-reference analysis on forty-seven multilateral environmental agreements for the period of 2007 to 2016. The keywordreference analysis is an advanced type of context analysis, ${ }^{30}$ useful for comparing documents on their similarity ${ }^{31}$ and further allowing researchers to analyze word frequencies in lexicographic studies..$^{32}$ We used the presence of certain keywords in treaty decision texts or the equivalent as an indicator of issue couplings to other environmental issues or other nonenvironmental pillars of sustainable development. These keyword references found in treaty decisions do not necessarily imply an institutionalized form of policy integration. However, these references create issue linkages that often advance and reflect a "soft form" of policy integration. Therefore, we argue that these keyword references provide useful means for mapping and assessing the extent of policy integration between multilateral environmental agreements. For example, the decisions adopted by the twelfth Conference of the Parties to the Convention on Biological Diversity contain several references to other environmental issues such as climate change or other issues such as health, most of which appear in

$30 \quad$ Hsieh and Shannon 2005 .

31 Sardinha 1999; Peirsman, Geeraerts, and Speelman 2010.

32 Kilgarriff 1996. 
dedicated decisions on these topics. ${ }^{33}$ We consider such references as reflecting efforts of treaty bodies to consider the nature of linkages across policy issues or domains and strengthen sustainability or environmental policy integration.

Selecting multilateral environmental agreements for this empirical analysis was not straightforward, given that the literature lacks a clear definition of multilateral environmental agreements ${ }^{34}$ and not the least the huge number of multilateral environmental agreements (over 1,300 at present). ${ }^{35}$ To ensure objectivity and reliability in the selection as well as broad representation of multilateral environmental agreements related to the Sustainable Development Goals, we chose the dataset on multilateral environmental agreements provided by the database InforMEA. ${ }^{36}$ This database is an initiative of the UN Environment Programme (UNEP) and included in 2018 fifty-three multilateral environmental agreements. Due to the unavailability of documents on decisions, however, we had to exclude six multilateral environmental agreements from the analysis, leading to a final sample of forty-seven multilateral environmental agreements.

For the analysis of sustainability policy integration, all forty-seven agreements were considered as concerned with the environmental pillar. Therefore, we did not differentiate the agreements into subgroups. For the analysis of environmental policy integration, however, we were interested in measuring the degree of integration between different issue clusters of multilateral environmental agreements. We thus classified the forty-seven agreements into six categories of specialization; namely, atmosphere, biodiversity, chemicals, climate, land, and oceans. Based on this categorization, we identified that three specialize on the atmosphere, eleven on biodiversity, five on chemicals, three on climate, one on land, and fifteen on oceans (see Annex 2 for the list of these agreements). Eight multilateral environmental agreements had no specific alignment with any environmental issue, and one multilateral environmental agreement is specialized on a social issue. Accordingly, these agreements were included in the analysis on sustainability policy integration, but excluded from the analysis on environmental policy integration. In the analysis, we operationalized policy integration through the frequency of keyword references to either their own institutional specialization or to other issues beyond this specialization.

33 Convention on Biological Diversity 2014a.

34 Kiss and Shelton 2007.

35 International Environmental Agreements Project Database (2016).

36 InforMEA Database (2016). 
We took the Sustainable Development Goals as a starting point for selecting the keywords. These goals resulted from an inclusive goal-setting process involving all members of the United Nations and representing internationally accepted norms that determine minimum acceptable values. ${ }^{37} \mathrm{We}$ considered the formulation of those norms and values in the 2030 Agenda text and particularly the Sustainable Development Goals to reflect how the international community frames and defines sustainable development. Information extracted from texts contains large terminological variation, complex contextual patterns, and even conflicting or fuzzy semantics. ${ }^{38}$ The terminological variation demanded the creation of keyword clusters instead of single keywords. These keyword clusters contain either synonyms, such as "biodiversity" as a synonym to "biological diversity," or words with distinctive meanings for a keyword cluster, such as the words "women" and "girls" that are represented in the keyword cluster "gender." 39 We divided the Sustainable Development Goals according to the three pillars of sustainable development (Table 1). In total, the list contains fifty-three keywords grouped in eighteen clusters.

We conducted our keyword reference analysis on decisions adopted at meetings of the main decision-making body of the forty-seven selected multilateral environmental agreements. For their regular operations, parties to a multilateral environmental agreement usually establish a decision-making body, where parties meet in intervals of one, two, or more years to discuss and decide over the implementation and development of the agreement. These include conferences or meetings of the parties, governing council meetings, or meetings of executive bodies. We did not differentiate between these different types of treaty bodies, but focused on the main or most important decision-making body, regardless of its legal title or form.

The keyword reference analysis proceeded in two steps. First, we made a text search query, using the qualitative software programme NVivo. We then evaluated the results with the statistics software SPSS. For the query with NVivo, we used two search options. For single keywords, such as "health," we used stemmed words; for word combinations, such as "drinking water," we used exact matches. This approach enabled gaining precise and reliable query results for the analysis. For subsequently evaluating the results with SPSS, we defined

37 Wilson and $\mathrm{Wu} 2 \mathrm{O} 17$.

$38 \quad$ Freitas et al. 2013 .

39 In the logic of the Sustainable Development Goals, we categorized "forests" to the cluster of biodiversity (Goal 15) and "economic growth" to the cluster of employment (Goal 8). 
TABLE 1 Keyword clusters for the keyword-reference analysis

$\begin{array}{lll}\text { Environment } & \text { Society } & \text { Economy }\end{array}$

\begin{tabular}{|c|c|c|c|}
\hline $\begin{array}{l}\text { Keyword } \\
\text { clusters }\end{array}$ & $\begin{array}{l}\text { Atmosphere (also: air pol- } \\
\text { lution, ozone) }\end{array}$ & $\begin{array}{l}\text { Education (also: life-long } \\
\text { learning) }\end{array}$ & Agriculture \\
\hline & $\begin{array}{l}\text { Biodiversity (also: bio- } \\
\text { logical diversity, forests, } \\
\text { deforestation, reforesta- } \\
\text { tion, afforestation) }\end{array}$ & $\begin{array}{l}\text { Equity (also: equality, fair- } \\
\text { ness, inequality, inequity, } \\
\text { injustice, justice) }\end{array}$ & Consumption \\
\hline & $\begin{array}{l}\text { Chemicals (also: haz- } \\
\text { ardous waste) }\end{array}$ & $\begin{array}{l}\text { Gender (also: girls, } \\
\text { women) }\end{array}$ & $\begin{array}{l}\text { Employment (also: decent } \\
\text { work, economic growth, } \\
\text { jobs) }\end{array}$ \\
\hline & $\begin{array}{l}\text { Climate (also: global } \\
\text { warming) }\end{array}$ & $\begin{array}{l}\text { Health }^{a} \text { (also: well-being, } \\
\text { sanitation, water and soci- } \\
\text { ety }^{b} \text { ) }\end{array}$ & Energy \\
\hline & $\begin{array}{l}\text { Land (also: desertification, } \\
\text { land degradation }{ }^{c} \text {, soil) }\end{array}$ & $\begin{array}{l}\text { Hunger (also: food, food } \\
\text { security, nutrition) }\end{array}$ & $\begin{array}{l}\text { Industrialization (also: } \\
\text { infrastructure, innovation) }\end{array}$ \\
\hline & $\begin{array}{l}\text { Oceans (also: marine, seas, } \\
\text { water and environment }{ }^{\mathrm{d}} \text { ) }\end{array}$ & Poverty & Production \\
\hline
\end{tabular}

a Environmental, ecosystems, and planetary health were excluded from the analysis.

b Water in societal context was defined as "drinking water, fresh water, clean water."

c Twice-appearing keywords were subtracted, for example, "land degradation" as a word combination was subtracted from "land" as a single word. Same for the word combination "food security," which was subtracted from the word "food."

d Water in environmental contexts.

parameters and variables. The parameters were the amount of words produced by multilateral environmental agreements and the amount of keywordreference counts in the documents. The variables were the frequencies of multilateral environmental agreements referring to keywords. Detailed elaborations on calculations are provided in footnotes to the Tables 2 and 3 and Figure 1.

We complemented the results of this analysis with reading a selected number of treaty decisions containing keyword references. The document analysis allowed us to study policy integration in the broader political and social context of sustainability governance. Furthermore, we could also pay attention to the role of the Millennium Development Goals and the Sustainable Development Goals on decisions of multilateral environmental agreements. 


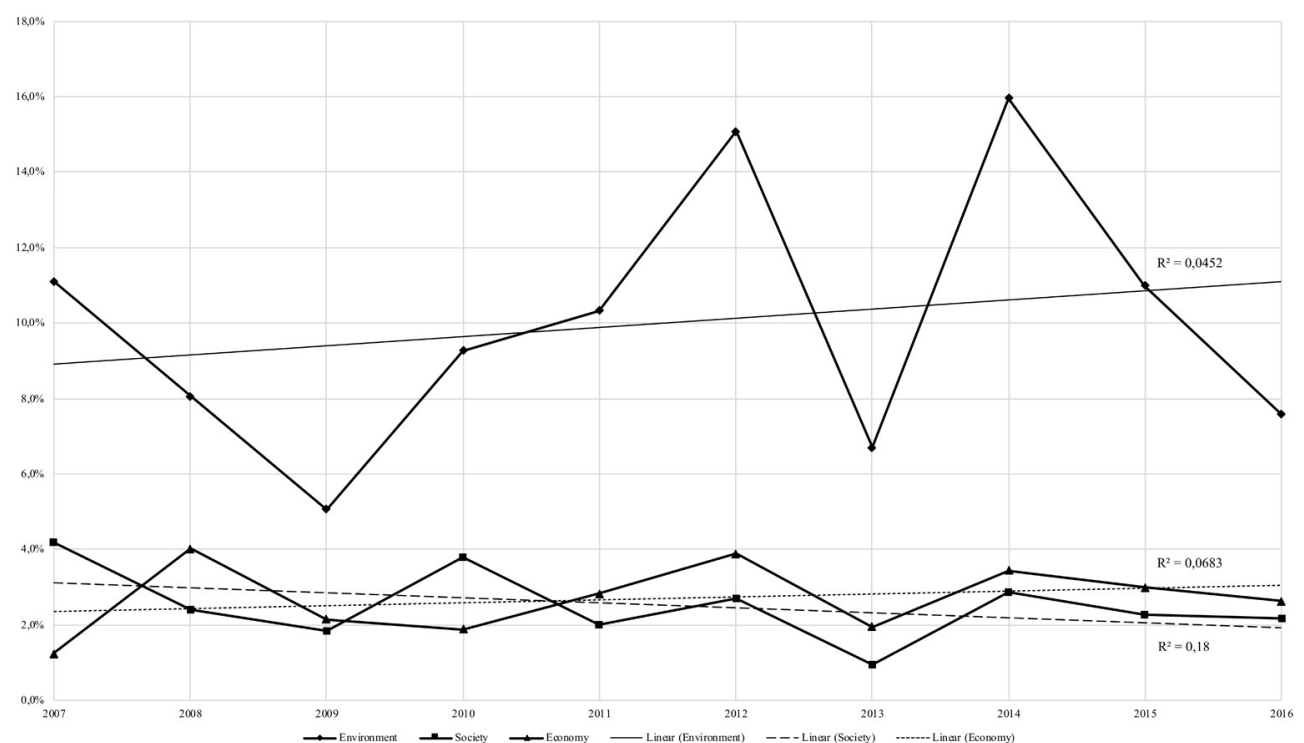

FIGURE 1 Reference counts of multilateral environmental agreements to the three pillars of sustainable development in 2007-2016

Note: Counts of keyword-references to each pillar per multilateral environmental agreement per meeting event. Results divided by total amount of words produced in respective meeting document are shown in percentages. Numbers accumulated and indicated per year for 2007-2016. Linear trendlines indicate average of keyword-reference counts throughout the measured decade.

\section{$3 \quad$ Results}

In this section, we present and discuss the results of the analysis of sustainability policy integration; that is, the integration of the three areas of environment, society, and economy in decisions by multilateral environmental agreements.

\subsection{Sustainability Policy Integration}

The overall pattern is shown in Figure 1. A key finding is that decisions by multilateral environmental agreements refer significantly more often to other environmental concerns than to keywords that relate to social or economic policies. We considered here also annual fluctuations that are mainly caused by different numbers of treaty body meetings; for example, all areas dropped in keyword references in 2013 partially because there were only eleven meetings in that year compared to twenty-two meetings in 2012 and twenty-three meetings again in 2014. This result indicates that, overall, multilateral environmental agreements are still poorly integrated with concerns from social policy or economic policy, and that the integration is still a major challenge ahead. 
However, there has been a small, but relatively constant, amount of crosspillar references to social and economic concerns (Figure 1). For example, gender issues have featured prominently in the past conferences of the parties to the UN Framework Convention on Climate Change as they have been taken up every year in their decisions since 2010. The term "sustainable development" appears twelve times in the Paris Agreement adopted in 2015 (the agreement was introduced in a decision, hence included in the analysis). Its objective is to "strengthen the global response to the threat of climate change, in the context of sustainable development and efforts to eradicate poverty." The explicit inclusion of poverty concerns in the objective is a significant change from the 1997 Kyoto Protocol, where the objective was simply "to promote sustainable development." ${ }^{\prime 0}$ Furthermore, the preamble of the 2015 Paris Agreement makes unprecedented references to other environmental and sustainability issues by requiring the parties to "respect, promote and consider their respective obligations on human rights, the right to health, the rights of indigenous peoples, local communities, migrants, children, persons with disabilities and people in vulnerable situations and the right to development, as well as gender equality, empowerment of women and intergenerational equity." The Preamble also includes references to "climate justice" as an important concept when taking action to address climate change, as well as to "education, training, public awareness, public participation, [and] public access to information." The politically more sensitive economic dimension of sustainable development features less prominently than the social dimension, but it does include wording similar to the Sustainable Development Goal on sustainable consumption and production. ${ }^{41}$ However, "economic growth" as such is not associated with the cause of climate change, but remains an ultimate goal to be promoted along with "long-term global response to climate change" and "sustainable development." 42

Notably, some of these references to nonenvironmental issues found in treaty decisions were made in conjunction with the Millennium Development Goals. For example, the parties to the Convention to Combat Desertification adopted a decision concerned about implications of desertification on the achievement of the Millennium Development Goals, specifically those relat-

$40 \quad$ Kyoto Protocol 1998, Article 2.1.

41 UNFCCC Paris Agreement 2015, Preamble: "Sustainable lifestyles and sustainable patterns of consumption and production, with developed country Parties taking the lead, play an important role in addressing climate change."

UNFCCC Paris Agreement 2015, Article 10.5. 
ing to the eradication of poverty and environmental sustainability. ${ }^{43}$ Similar references can be found in the Ramsar resolution on the "integrated framework for linking wetland conservation and wise use with poverty eradication, ${ }^{24}$ as well as the Convention on Biological Diversity decision on "biodiversity for poverty eradication and sustainable development." ${ }^{45}$ The Millennium Development Goals have also had a considerable impact on the decisions of the Water Convention, especially for its Protocol on Water and Health. ${ }^{46}$ These are just a few examples that we have chosen as illustration to show some impact and utility of the global goals on the work of the treaty bodies of multilateral environmental agreements.

Despite the observed progress toward sustainability policy integration, overall the international policies on sustainability governance seem to be insufficiently integrated, given the limited references that we identified from multilateral environmental agreements to nonenvironmental concerns. Multilateral environmental agreements, so far, have not effectively enhanced the level of sustainability policy integration across the environmental, economic, and social pillars of sustainable development. The three policy domains remain marked by a wide range of issues, interests, and political actors that differ in their approaches, institutions, and policies for sustainability, based on different assumptions and conflicting notions, ${ }^{47}$ all of which seem to still make it difficult to transform them into one single consistent policy program at the global level. ${ }^{48}$

\subsection{Environmental Policy Integration}

We now present the results of the empirical analysis of environmental policy integration; that is, the extent to which multilateral environmental agreements have integrated environmental issue areas outside their institutional specialization. For this analysis, we have clustered the forty-seven multilateral environmental agreements according to six main environmental concerns that they are addressing; namely, atmospheric pollution, biodiversity loss, chemical pollution, climate change, land degradation, and marine pollution. Table 2 shows

\footnotetext{
43 Convention to Combat Desertification 2013.

44 Ramsar Convention 2012a, Resolution XI.13.

45 Convention on Biological Diversity 2014 b.

46 Water Convention 2007.

47 Ratner 2004.

48 Frödin 2015, 451.
} 
TABLE 2 Reference counts of multilateral environmental agreement clusters to their own institutional specialization and issue areas of nonspecialization in 2007-2016 (numbers indicated in percentages)

$\begin{array}{cccccc}\begin{array}{c}\text { Atmosphere } \\ \text { cluster }\end{array} & \begin{array}{c}\text { Biodiversity } \\ \text { cluster }\end{array} & \begin{array}{c}\text { Chemicals } \\ \text { cluster }\end{array} & \begin{array}{c}\text { Climate } \\ \text { cluster }\end{array} & \begin{array}{c}\text { Land } \\ \text { cluster }\end{array} & \begin{array}{c}\text { Oceans } \\ \text { cluster }\end{array}\end{array}$

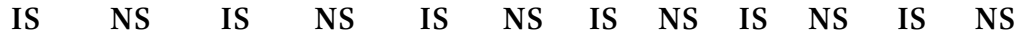

$\begin{array}{rrrrrrrrrrrrr}2007 & 0.5 & 0.1 & 0.1 & 0.1 & 0.4 & 0.1 & 0.3 & 0.1 & 0.9 & 0.3 & 2.9 & 0.5 \\ 2008 & 0.9 & 0.2 & 1.9 & 1.7 & 1.4 & 0.2 & 0.0 & 0.0 & 0.0 & 0.0 & 0.5 & 0.2 \\ 2009 & 0.2 & 0.1 & 0.3 & 0.0 & 1.2 & 0.1 & 0.2 & 0.2 & 0.6 & 0.3 & 1.0 & 0.4 \\ 2010 & 0.9 & 0.0 & 2.1 & 0.9 & 0.9 & 0.2 & 0.3 & 0.1 & 0.0 & 0.0 & 2.1 & 0.2 \\ 2011 & 3.2 & 0.5 & 0.5 & 0.5 & 1.7 & 0.2 & 0.2 & 0.2 & 0.5 & 0.1 & 0.4 & 0.1 \\ 2012 & 1.3 & 0.5 & 2.0 & 1.3 & 1.3 & 0.3 & 0.3 & 0.3 & 0.0 & 0.0 & 6.1 & 1.4 \\ 2013 & 0.4 & 0.1 & 0.3 & 0.0 & 1.8 & 0.8 & 0.2 & 0.2 & 0.7 & 0.1 & 0.6 & 0.2 \\ 2014 & 2.6 & 0.1 & 2.3 & 1.1 & 1.2 & 0.2 & 0.2 & 0.0 & 0.0 & 0.0 & 5.4 & 1.0 \\ 2015 & 0.7 & 0.1 & 0.8 & 1.2 & 1.7 & 0.3 & 0.2 & 0.1 & 0.8 & 0.3 & 3.8 & 0.7 \\ 2016 & 1.3 & 0.1 & 1.9 & 0.7 & 0.9 & 0.0 & 0.2 & 0.1 & 0.0 & 0.0 & 1.3 & 0.5 \\ \text { Total } & 12.1 & 1.9 & 12.2 & 7.5 & 12.7 & 2.5 & 2.2 & 1.4 & 3.7 & 1.0 & 23.9 & 5.1\end{array}$

Note: Means: 7.2; IS: institutional specialization; NS: nonspecialization (referred to environmental issue areas). Keyword-reference counts of 1) institutional specialization and 2) environmental issue areas of nonspecialization recorded per multilateral environmental agreement and per meeting event. Results divided by total number of words produced in respective meeting documents. Numbers accumulated per multilateral environmental agreement cluster and single years for 2007-2016.

these clusters of multilateral environmental agreements and the reference distribution to their own institutional specializations and issue areas of nonspecialization from 2007 to 2016.

Multilateral environmental agreements displayed stable proportions of references to their own specialization and-much less-to issue areas they are not specialized in throughout the assessment period. There are no reference leaps to other environmental issue areas, but rather a static focus on their own subject area. Except for biodiversity protection where multilateral environmental agreements referred to oceans more frequently, all clusters of multilateral environmental agreements were largely self-referential and did not refer to other environmental issues in their decisions (Table 3). This result indicates that most clusters of multilateral environmental agreements followed a path of sectoral fragmentation within the broader field of environmental policy. 
TABLE 3 Reference counts of clusters of multilateral environmental agreements to issue areas (numbers in percentages)

\begin{tabular}{lccccccc}
\hline Clusters & $\begin{array}{c}\text { Atmosphere } \\
\text { issue area }\end{array}$ & $\begin{array}{c}\text { Biodiversity } \\
\text { issue area }\end{array}$ & $\begin{array}{c}\text { Chemicals } \\
\text { issue area }\end{array}$ & $\begin{array}{c}\text { Climate } \\
\text { issue area }\end{array}$ & $\begin{array}{c}\text { Land } \\
\text { issue area }\end{array}$ & $\begin{array}{c}\text { Oceans } \\
\text { issue area }\end{array}$ & $\begin{array}{c}\text { Average } \\
\text { Atmosphere }\end{array}$ \\
Biodiversity & 12.1 & 0.1 & 0.5 & 0.9 & 0.2 & 0.2 & 2.3 \\
Chemicals & 0.0 & 12.2 & 0.1 & 1.8 & 1.3 & 4.2 & 3.3 \\
Climate & 0.2 & 0.0 & 12.7 & 0.9 & 0.5 & 0.9 & 2.5 \\
Land & 0.0 & 0.7 & 0.0 & 2.2 & 0.3 & 0.2 & 0.6 \\
Oceans & 0.1 & 0.4 & 0.0 & 0.5 & 3.7 & 0.1 & 0.8 \\
Average & 2.1 & 2.8 & 0.4 & 1.3 & 1.5 & 23.9 & 4.8 \\
& & 2.5 & 2.3 & 1.3 & 1.2 & 4.9 & 2.4 \\
\hline
\end{tabular}

Note: Counts of keyword-references to institutional specialization and single environmental issue areas of nonspecialization recorded per multilateral environmental agreement and per meeting event. Results divided by total amount of words produced in respective meeting documents. Numbers accumulated per cluster of multilateral environmental agreements. Averages were calculated by excluding self-reference scores.

Considering a general perception of negotiation fatigue ${ }^{49}$ in a matured treaty system, ${ }^{50}$ the results correspond to other studies that observe that treaty bodies are increasingly interested in "thickening" their original treaty objectives and obligations; in adjusting interpretations and adapting commitments in response to their subsidiary bodies, namely scientific and technical advisers; and in developing strategic frameworks, all of which tends to lead to increasingly self-referential clusters of agreements. ${ }^{51}$ Such sectoral fragmentation, which is also documented in the empirical analysis, has been discussed by numerous scholars. Some fear that sectoral fragmentation threatens the integrity of international law by creating legal and doctrinal inconsistencies. ${ }^{52}$ Others point to norm conflicts as a consequence of fragmentation, emphasizing that not only treaties, but also decisions by treaty bodies, can be in conflict. ${ }^{53}$ Martti Koskenniemi sees sectoral fragmentation linked to increasing deformalization of international law. ${ }^{54} \mathrm{He}$ argues that, as a result of deformalization, most multilateral agreements are laying down broad standards and procedures rather than "clear behavioural directives, enabling the pursuit of

\footnotetext{
49 Muñoz, Thrasher, and Najam 2009.

50 Kim 2013, 985; Wiersema 2010, 274.

$5^{1} \quad$ Carlarne 2008.

52 Fischer-Lescano and Teubner 2004, 1001-1002.

53 van Asselt 2008.

54 Koskenniemi 2005.
} 
negotiations well into the time after the formal entry into force of the treaty."55 The increasingly self-referential character of multilateral environmental agreements that we observed, is in this perspective subverting the multidimensional and cross-sectoral nature of environmental problems. ${ }^{56}$ As a consequence, institutional isolation might create less effective global institutions as they try to manage complex interrelated systems in a piecemeal fashion. ${ }^{57}$ More effective environmental policy integration, however, would require that environmental treaties take complexities and interdependencies within ecosystems better into consideration. For multilateral environmental agreements this would mean to better identify overlapping themes across regimes and to develop better strategies for interinstitutional cooperation and coordination.

And indeed, after the 2012 UN Conference on Sustainable Development in Rio de Janeiro, several multilateral environmental agreements expressed their desire for such enhanced cooperation, collaboration, and synergies. Examples are the Convention on Migratory Species that stressed the importance of enhancing cooperation on cross-cutting issues, ${ }^{58}$ the Convention on Biological Diversity that aimed for improving synergies and processes among biodiversity-related conventions, ${ }^{59}$ the Convention on International Trade in Endangered Species of Wild Fauna and Flora that aimed to develop and strengthen cooperation across organizations and multilateral environmental agreements, ${ }^{60}$ and the Ramsar Convention that aspired collaboration with other agreements such as the Agreement on the Conservation of AfricanEurasian Migratory Waterbirds and the Water Convention. ${ }^{61}$

To bring about practical results beyond rhetoric, many treaties also formulated concrete decisions to strengthen synergies and cooperation. ${ }^{62}$ Especially biodiversity-related conventions attempted to implement actions at international, national, and regional levels for achieving shared goals of conservation

$55 \quad$ Koskenniemi 2005.

56 Carlarne 2008, $45^{2}$.

57 Carlarne 2008, 464 .

58 Convention on Migratory Species 2014.

59 Convention on Biological Diversity 2012a; see also Convention on Biological Diversity 2014c.

6o "Sixteenth Meeting of the Conference of the Parties of the Convention on International Trade in Endangered Species of Wild Fauna and Flora (CITES COP16)" 2013.

61 "Eleventh Meeting of the Conference of the Parties (COP11) of the Ramsar Convention on Wetlands" 2012.

62 Convention on Biological Diversity 2012b; Convention on International Trade in Endangered Species of Wild Fauna and Flora 2013; Ramsar Convention 2012b. 
and sustainable use. In meeting their objectives, the conventions developed a number of complementary approaches (site, species, genetic resources, or ecosystem based) and operational tools (e.g., programs of work, trade permits and certificates, multilateral systems for access and benefit sharing, regional agreements, site listings, and funds). ${ }^{63} \mathrm{~A}$ recent effort in 2016 of the biodiversity agreements was to map multilateral biodiversity agreements to the Aichi Biodiversity Targets. ${ }^{64}$ This collaborative action was taken for understanding the "plethora of guiding decisions of the biodiversity-related conventions," enhancing synergies, ${ }^{65}$ and improving efficiency among treaties. Nonetheless, cooperation and coordination efforts between multilateral biodiversity agreements face operational difficulties. According to José Octavio Velásquez Gomar, who analyzed policy integration in the biodiversity field, convention bodies and governments are overwhelmed by the implementation of multiple decisions adopted by governing bodies and their regular meetings. Therefore, interinstitutional collaboration has been undermined. ${ }^{66}$ Despite the mutual interest of the treaties in building on synergies, their objectives and memberships are diverse, their relationships remain characterized by discord, and the synergistic effects of cooperation are not reciprocally beneficial and lack equal recognition. ${ }^{67}$

\section{$4 \quad$ Will the Sustainable Development Goals and the Global Pact Change Matter?}

The general trends as observed through this analysis indicate that multilateral environmental agreements need to better integrate environmental concerns with social and economic issues. Although we observed some effects through a small number of impactful treaty decisions, the keyword-reference analysis shows that the levels of policy integration between the three pillars of sustainable development have remained more or less the same in the 2007-2016 period. We did not find a clear trend towards further policy integration. A transformative catalyst may thus be required to break out of what appears to be an equilibrium until 2016. We discuss now two recent initiatives that some believe might have

\footnotetext{
63 Convention on Biological Diversity 2015.

64 UNEP-WCMC 2015.

65 UNEP 2016.

66 Velázquez Gomar 2016.

67 Corning 1998.
} 
such catalytic force: the Sustainable Development Goals that were agreed to in 2015, and the Global Pact for the Environment that is currently being negotiated.

As for the Sustainable Development Goals, it is striking that the earlier Millennium Development Goals did have some impact on the policy integration efforts of multilateral environmental agreements. Because this analysis ended with 2016, however, it remains to be seen to what extent the Sustainable Development Goals will bring even more new impetus to enhancing policy integration between international institutions.

Some commentators seem to be pessimistic. They criticize the goals for merely mirroring the existing fragmentation of global governance, ${ }^{68}$ and argue that the environmental pillar is arbitrarily divided up into three issues (climate change, terrestrial biodiversity, and marine biodiversity), as well as water and energy policies - all covered by separate goals. Although the Sustainable Development Goals address the objectives of some of the key multilateral environmental agreements, the lack of integration between these objectives in the framework of the Sustainable Development Goals and their targets might imply a missed opportunity.

Other observers, however, are more positive about the Sustainable Development Goals, ${ }^{69}$ and see the goals as an institutionalized global goal set with systematic coverage of interdependent issues. Undoubtedly, the 17 goals and their 169 targets are clearly presented as "integrated and indivisible," balancing out the three dimensions of sustainable development. ${ }^{70}$ Furthermore, Target 17.14 stresses the need to "enhance policy coherence for sustainable development," and encourages governments to put in place a mechanism to that end. The optimistic commentators argue that there is a potential for the Sustainable Development Goals to penetrate or bring into line existing multilateral agreements established primarily for other purposes.

While it is too early to assess the impact of the Sustainable Development Goals on the integrative force of the multilateral environmental agreements that we studied, it is remarkable that a number of multilateral environmental agreements have already begun referring to the goals as a set of higher-order global priorities to which their specific policies and measures should aim to contribute. For example, the Convention on International Trade in Endangered Species of Wild Fauna and Flora has called for establishing cooperation, col-

68 Kim 2016; Underdal and Kim 2017.

69 Stevens and Kanie 2016.

70 UN General Assembly, Resolution A/RES/70/1, Preamble (2015b). 
laboration, and synergies between the convention and the 2030 Agenda. ${ }^{71}$ The Water Convention underlined the need for enhanced cross-sector and transboundary cooperation for the implementation of the 2030 Agenda and the Sustainable Development Goals. ${ }^{72}$ More significantly, we observed instances where multilateral environmental agreements used the Sustainable Development Goals to motivate or justify linking up to various other sustainability issues. For example, the parties to the Convention on Wetlands recognized "a direct relevance to the achievement of any Sustainable Development Goals which are related to poverty eradication, food and nutrition, healthy living, gender equality, water quality and supply, water security, energy supply, reduction of natural disasters, innovation and the development of appropriate infrastructure, sustainable human settlements, adaptation to climate change, oceans, seas and marine resources, biodiversity and sustainable use of ecosystems."73 Furthermore, in a decision of the Convention to Combat Desertification, ${ }^{74}$ it was recalled by the parties that, in striving to achieve Target 15.3 on desertification, "it is also important to address wider elements of the 2030 Agenda, including, inter alia, ending poverty and hunger, tackling inequality, empowering women and stimulating economic growth." Similarly, the Convention on Long-Range Transboundary Air Pollution recognized the linkages between the convention and the goals on hunger, health, energy, industry, consumption and production, climate action, life below water, and life on land, and decided to reflect those linkages in its future work. As such, major multilateral environmental agreements have started to seek to advance policy integration through the framework of the Sustainable Development Goals. ${ }^{75}$

The transformative potential of the Sustainable Development Goals would depend not only on the design of goals and targets, but also on the effectiveness of governance arrangements that would diffuse the goals and integrate them into existing institutions. This process is sometimes called "orchestration" and is facilitated by international organizations. ${ }^{76}$ The High-Level Political Forum on Sustainable Development is a prominent example of such an organization playing the role of an orchestrator, with a mandate of enhancing integration, coordination, and coherence across the UN system. It serves as the main UN platform through which treaty bodies of multilateral environmental

\footnotetext{
71 Convention on International Trade in Endangered Species of Wild Fauna and Flora 2016.

72 Water Convention 2015.

73 Ramsar Convention 2015.

74 Convention to Combat Desertification 2015.

75 Nilsson, Griggs, and Visbeck 2016.

76 Abbott and Bernstein 2015.
} 
agreements, among other actors such as governments, can promote the coordination of policies and integrate the goals into their decisions and practices. ${ }^{77} \mathrm{To}$ that end, the High-Level Political Forum invites relevant treaty bodies to participate in their work. According to the reports of the Earth Negotiations Bulletin, a few key multilateral environmental agreements such as the Convention on Wetlands and the Convention on Biological Diversity have been particularly vocal during the annual meetings of the High-Level Political Forum..$^{78}$ However, it remains to be seen to what extent this potential orchestrator will affect future decisions of multilateral environmental agreements and enhance policy integration. ${ }^{79}$

Another key orchestrator of particular relevance to the work of multilateral environmental agreements is the UN Environment Programme (UNEP). ${ }^{80}$ As the main agency of the United Nations responsible for coordinating the organization's environmental activities, UNEP coordinates various efforts in the environmental dimension of the 2030 Agenda, with a specific mandate on enhancing synergies between the Sustainable Development Goals and multilateral environmental agreements. In its sixth Global Environment Outlook, UNEP identified that the implementation of these agreements may benefit from a more integrated approach through greater linkages with the Sustainable Development Goals. ${ }^{81}$ However, UNEP does not pay equal consideration to all environmental goals. As reflected in the selected group of environmental indicators for which UNEP identifies itself as a "custodian agency," special attention is paid to six goals on water, economic growth, consumption and production, life below water, life on land, and partnerships, while energy and climate change goals are excluded. The exclusion of these two goals on climate change and energy limits the orchestration potential of UNEP. How the Sustainable Development Goals will be incorporated into the work of UNEP, in particular to its coordination work of multilateral environmental agreements, is a future research question to be addressed.

In addition to the 2015 Sustainable Development Goals, another key development in recent years is the 2018 decision by the UN General Assembly to negotiate a Global Pact for the Environment. This decision followed the presentation of a draft Global Pact for the Environment by the French think tank, Le

\footnotetext{
77 Bernstein 2017.

78 "HPLF 2018 Highlights" 2018.

79 "Summary of the 2018 Meeting of the High-Level Political Forum on Sustainable Development" 2018.

8o Biermann 2014.

81 UNEP 2016.
} 
Club de Juristes, which coordinated an expert-driven drafting process involving over 100 lawyers. Now, a new intergovernmental process will be coordinated by an ad hoc open-ended working group created by the General Assembly. This is a major development, given that such a framework agreement could help confront the high levels of fragmentation across the multilateral environmental agreements. But will it succeed in bringing separate institutions together and enhance policy integration?

Overall, the draft Global Pact does not follow an issue-based approach like the Sustainable Development Goals, but rather lists general principles of international environmental law such as integration, equity, and precaution that are applicable across all issue areas. Here, the exact formulation of the "principle of integration" will be a key determinant to the effectiveness of the Global Pact for policy integration across the three pillars of sustainable development.

We observe that the draft pact focuses on enhancing what we called in this article "sustainability policy integration." This would potentially lead to an increase in the number of references to other sustainability issues in future decisions of multilateral environmental agreements. Critically, however, the draft provision on integration does not provide guidance as to how to integrate "the requirements of environmental protection into the planning and implementation of their policies and national and international activities" for the pursuit of sustainable development. Should the environment not be prioritized in certain situations? ${ }^{82}$ Furthermore, the draft Global Pact pays little consideration on integration of various environmental objectives and decisions of multilateral environmental agreements. It makes references to three environmental issues; that is, "the fight against climate change, the protection of oceans and the maintenance of biodiversity," without substantiating why these three are referenced. One could suspect that these might have been derived from the three main environmental Sustainable Development Goals 13, 14, and 15. Furthermore, it declares that "every person has the right to live in an ecologically sound environment adequate for their health, well-being, dignity, culture and fulfilment," but does not indicate as to how potential conflicts between different environmental rights should be resolved.

The literature on international environmental law and governance suggests that the chances of such a framework environmental agreement being successful in integrating environmental policies will increase if it contained a clearly defined environmental objective. Such an objective could then serve as a shared purpose to which specific objectives of all multilateral environmental 
agreements must contribute. ${ }^{83}$ However, such a key overarching environmental objective is missing from the current draft of the Global Pact. ${ }^{84}$

\section{$5 \quad$ Conclusion}

This study provides insights into sustainability and environmental policy integration of multilateral environmental agreements. We mapped environmental, social, and economic issue areas in decisions of forty-seven multilateral environmental agreements and elaborated on policy integration in the post-2015 era. Regarding sustainability policy integration, this analysis shows structural patterns of the integration of the environmental, social, and economic areas of sustainable development in decisions of multilateral environmental agreements. We illustrated that multilateral environmental agreements refer for the most part only to environmental issue areas, and much less so to social and economic concerns. This study of environmental policy integration identifies a mostly self-referential and sectorally fragmented system of multilateral environmental agreements, which is challenged to cooperate across and within clusters of multilateral environmental agreements. Overall, more research is needed on these relationships in the system of multilateral environmental agreements, within and across clusters.

In sum, the system of multilateral environmental agreements over the period 2007-2016 does not seem to be moving towards more policy integration. If policy integration is a key mission of the Sustainable Development Goals, overcoming these shortcomings by improving interinstitutional relationships is of vital importance. More detailed follow-up research that includes the next decade in decisions by multilateral environmental agreements would therefore be useful to augment our current analysis.

\section{Bibliography}

Abbott, Kenneth W., and Steven Bernstein. "The High-Level Political Forum on Sustainable Development: Orchestration by Default and Design." Global Policy 6 (2015), 222-233.

83 Kim and Bosselmann 2013; Anton 2012; Kim and Mackey 2014; Bridgewater, Kim, and Bosselmann 2014.

84 Kim and Bosselmann 2015. 
Abbott, Kenneth W., Jessica F. Green, and Robert. O. Keohane. "Organizational Ecology in World Politics: Institutional Density and Organizational Strategies." Paper presented at the Annual Convention of the International Studies Association, San Francisco, April 2013.

Adelle, Camilla, and Duncan Russel. “Climate Policy Integration: A Case of Déjà Vu?” Environmental Policy and Governance 23 (1) (2013), 1-12.

Anton, Donald K. "The 2012 United Nations Conference on Sustainable Development and the Future of International Environmental Protection." Consilience: The Journal of Sustainable Development 7 (2012), 55-61.

Benvenisti, Eyal, and George W. Down. “The Empire's New Clothes: Political Economy and the Fragmentation of International Law." Stanford Law Review 6o (2007), 595631.

Bernstein, Steven. "The United Nations and the Governance of Sustainable Development Goals." In Governing through Goals: Sustainable Development Goals as Governance Innovation, eds. Norichika Kanie and Frank Biermann (Cambridge: MIT Press, 2017), 213-239.

Biermann, Frank. Earth System Governance: World Politics in the Anthropocene (Cambridge: MIT Press, 2014).

Biermann, Frank, Olwen Davies, and Nicolien van der Grijp. "Environmental Policy Integration and the Architecture of Global Environmental Governance." International Environmental Agreements 9 (2009), 351-369.

Biermann, Frank, Norichika Kanie, and Rakhyun E. Kim. "Global Governance by GoalSetting: The Novel Approach of the UN Sustainable Development Goals." Current Opinion in Environmental Sustainability 26-27 (2017), 26-31.

Briassoulis, Helen. "Policy Integration for Complex Policy Problems: What, Why and How." Paper presented at the conference "Greening of Policies: Interlinkages and Policy Integration," Berlin, December 2004.

Bridgewater, Peter, Rakhyun E. Kim, and Klaus Bosselmann. "Ecological Integrity: A Relevant Concept for International Environmental Law in the Anthropocene?" Yearbook of International Environmental Law 25 (2014), 61-78.

Bull, Keith, Robert Hoft, and Mark A. Sutton. "Coordinating European Nitrogen Policies between International Conventions and Intergovernmental Organizations." In The European Nitrogen Assessment, eds. Mark A. Sutton, Clare M. Howard, Jan W. Erisman, Gilles Billen, Albert Bleeker, Peringe Grennfelt, Hans van Grinsven, and Bruna Grizzetti (Cambridge: Cambridge University Press, 2011), 570-584.

Carlarne, Cinnamon P. “Good Climate Governance: Only a Fragmented System of International Law Away?" Law and Policy 30 (2008), 450-480.

Chambers, Bradnee W. Interlinkages and the Effectiveness of Multilateral Environmental Agreements (Tokyo: United Nations University Press, 2008).

Chasek, Pamela S., and Lynn M. Wagner. The Roads from Rio: Lessons Learned from 
Twenty Years of Multilateral Environmental Negotiations (New York: Taylor \& Francis, 2012).

Convention on Biological Diversity. 2012a. UNEP/CBD/COP/11/17 and INF/11, 27, 30, 31, 41, 44, 46, 52/Rev.1, COP 11.

Convention on Biological Diversity. 2012b. UNEP/CBD/COP/11/L.16, COP 11.

Convention on Biological Diversity. 2014a. UNEP/CBD/COP/12/29, COP 12, Decision XII/2O on "Biodiversity and Climate Change and Disaster Risk Reduction" and Decision XII/21 on "Biodiversity and Human Health." Accessed 22 July 2017, https:// www.cbd.int/doc/meetings/cop/cop-12/official/cop-12-29-en.pdf.

Convention on Biological Diversity. 2014b. UNEP/CBD/COP/DEC/XII/5, COP 12, Decision XII/5. Accessed 18 July 2017, https://www.cbd.int/doc/decisions/cop-12/cop-12 -dec-o5-en.pdf.

Convention on Biological Diversity. 2014c. UNEP/CBD/COP/12/L.27, COP 12.

Convention on International Trade in Endangered Species of Wild Fauna and Flora. 2013. COP16 Com.II.5, COP 16.

Convention on International Trade in Endangered Species of Wild Fauna and Flora. 2016. COP 17. Accessed 8 June 2017, https://cites.org/node/4846o.

Convention on Migratory Species. 2014. UNEP/CMS/Resolution 11.10, COP 11. Accessed 12 May 2017, http://www.cms.int/sites/default/files/document/Res_11_10_Synergies _and_Partnerships_E_o.pdf.

Convention to Combat Desertification. 2013. ICCD/COP(11)/23/Add.1, COP 11, UNCCD Decision $7 /$ COP.11. Accessed 18 October 2016, https://www.unccd.int/sites/default/ files/sessions/documents/ICCD_COP11_23_Add.1/23addieng.pdf.

Convention to Combat Desertification. 2015. ICCD/COP(12)/2o/Add.1, UNCCD Decision $3 /$ COP.12. Accessed 10 October 2016, https://www.unccd.int/sites/default/files/ inline-files/dec3-COP.12eng.pdf.

Corning, Peter A. "The Synergism Hypothesis: On the Concept of Synergy and Its Role in the Evolution of Complex Systems." Journal of Social and Evolutionary Systems 21 (2) (1998), 133-172.

Drezner, Daniel W. "The Power and Peril of International Regime Complexity." Perspectives on Politics 7 (2009), 65-70.

"Eleventh Meeting of the Conference of the Parties (COP11) of the Ramsar Convention on Wetlands." Earth Negotiations Bulletin (2012). Accessed 28 August 2017, http://enb .iisd.org/ramsar/cop11/.

Fischer-Lescano, Andreas, and Gunther Teubner. "Regime-Collisions: The Vain Search for Legal Unity in the Fragmentation of Global Law." Michigan Journal of International Law 25 (2004), 999-1046.

Freitas, André, Seán O'Riain, Edward Curry, João C.P. da Silva, and Danilo S.C. Carvalho. "Representing Texts as Contextualized Entity-Centric Linked Data Graphs." In Proceedings - International Workshop on Database and Expert Systems Applications (DEXA) 662136o, (2013), 133-137. 
Frödin, Olle. "Researching Governance for Sustainable Development: Some Conceptual Clarifications." Journal of Developing Societies 31 (4) (2015), 447-466.

"HLPF 2018 Highlights." Earth Negotiations Bulletin (2018). Accessed 20 August 2018, http://enb.iisd.org/download/pdf/enb3342e.pdf.

Hogl, Karl, Daniela Kleinschmitt, and Jeremy Reyner. "Achieving Policy Integration Across Fragmented Policy Domains: Forests, Agriculture, Climate and Energy." Environment and Planning C: Government and Policy 34 (2016), 399-414.

Hsieh, Hsiu-Fang, and Sarah E. Shannon. "Three Approaches to Qualitative Content Analysis." Qualitative Health Research 15 (2005), 1277-1288.

InforMEA Database. 2016. Accessed 27 February 2016, https://www.informea.org/en.

International Environmental Agreements Project Database. 2016. Accessed 3 February 2016, https://iea.uoregon.edu.

Jordan, Andrew, and Andrea Lenschow. "Policy Paper Environmental Policy Integration: A State of the Art Review." Environmental Policy and Governance 20 (3) (2010), 147-158.

Keohane, Robert O., and David G. Victor. "The Regime Complex for Climate Change.” Perspectives on Politics 9 (1) (2011), 7-23.

Kilgarriff, Adam. "Comparing Word Frequencies Across Corpora: Why Chi-square doesn't work and an improved LOB-Brown comparison." Paper presented at the Joint International Conference of the Association for Literary and Linguistic Computing and the Association for Computers and the Humanities (ALLC-ACH) Conference, Bergen, June 1996.

Kim, Rakhyun E. "The Emergent Network Structure of the Multilateral Environmental Agreement System." Global Environmental Change 23 (2013), 980-991.

Kim, Rakhyun E. "The Nexus between International Law and the Sustainable Development Goals." Review of European, Comparative and International Environmental Law 25 (2016), 15-26.

Kim, Rakhyun E., and Klaus Bosselmann. "International Environmental Law in the Anthropocene: Towards a Purposive System of Multilateral Environmental Agreements." Transnational Environmental Law 2 (2013), 285-309.

Kim, Rakhyun E., and Klaus Bosselmann. "Operationalizing Sustainable Development: Ecological Integrity as a Grundnorm of International Law." Review of European, Comparative and International Environmental Law 24 (2015), 194-208.

Kim, Rakhyun E., and Brendan Mackey. "International Environmental Law as a Complex Adaptive System." International Environmental Agreements: Politics, Law and Economics 14 (2014), 5-24.

Kim, Rakhyun E., and Harro van Asselt. "Global Governance: Problem Shifting in the Anthropocene and the Limits of International Law." In Research Handbook on International Law and Natural Resources, eds. Elisa Morgera and Kati Kulovesi (Cheltenham: Edward Elgar, 2016), 473-495. 
Kiss, Alexandre C., and Dinah Shelton. Guide to International Environmental Law (Leiden: Martinus Nijhoff, 2007).

Koskenniemi, Martti. “International Legislation Today: Limits and Possibilities." Wisconsin International Law Journal 23 (1) (2005), 61-92.

Lafferty, William, and Eivind Hovden. "Environmental Policy Integration: Towards an Analytical Framework." Environmental Politics 12 (2003), 1-22.

Muñoz, Miquel, Rachel Thrasher, and Adil Najam. "Measuring the Negotiation Burden of Multilateral Environmental Agreements." Global Environmental Politics 9 (2009), $1-13$.

Nilsson, Måns, Dave Griggs, and Martin Visbeck. "Map the Interactions between Sustainable Development Goals." Nature 534 (2016), 320-322.

Nilsson, Måns, and Åsa Persson. "Policy Note: Lessons from Environmental Policy Integration for the Implementation of the 2030 Agenda." Environmental Science and Policy 78 (2017), 36-39.

Peirsman, Yves, Dirk Geeraerts, and Dirk Speelman. "The Automatic Identification of Lexical Variation between Language Varieties." Natural Language Engineering 16 (4) (2010), 469-491.

Perez, Oren. "Multiple Regimes, Issue Linkage, and International Cooperation: Exploring the Role of the WTO." University of Pennsylvania Journal of International Economic Law 26 (2005), 735-777.

Prost, Mario, and Paul Kingsley Clark. "Unity, Diversity and the Fragmentation of International Law: How Much Does the Multiplication of International Organizations Really Matter?" Chinese Journal of International Law 5 (2) (2006), 341-370.

Ramsar Convention. 2012a. Resolution XI.13. Accessed 10 June 2016, https://www.ram sar.org/sites/default/files/documents/pdf/guide/guide-poverty-e.pdf.

Ramsar Convention. 2012b. COP 11, DR.6 Rev.2.

Ramsar Convention. 2015. Resolution XII.2, COP 12. Accessed 8 June 2017, https://www .ramsar.org/sites/default/files/documents/library/cop12_reso2_strategic_plan_e_o .pdf.

Ratner, Blake D. "Sustainability as a Dialogue of Values: Challenges to the Sociology of Development." Sociological Inquiry 74 (1) (2004), 50-69.

Runhaar, Hens, Peter Driessen, and Caroline Uittenbroek. "Towards a Systematic Framework for the Analysis of Environmental Policy Integration." Environmental Policy and Governance 24 (2014), 233-246.

Sachs, Jeffrey D. "From Millennium Development Goals to Sustainable." Lancet 379 (2012), 2206-2211.

Sardinha, Tony B. "Using Keywords in Text Analysis: Practical Aspects." Direct Papers, Working Paper No. 42 (Liverpool: Liverpool University, 1999). Accessed 15 February 2018, http://www2.lael.pucsp.br/direct/DirectPapers42.pdf.

"Sixteenth Meeting of the Conference of the Parties of the Convention on Interna- 
tional Trade in Endangered Species of Wild Fauna and Flora (CITES COP16)." Earth Negotiations Bulletin (2013). Accessed 28 August 2017, http://enb.iisd.org/cites/ cop16/.

Steiner, Achim, Lee A. Kimbell, and John Scanlon. "Global Governance for the Environment and the Role of Multilateral Environmental Agreements in Conservation." Oryx 37 (2003), 227-237.

Stevens, Casey, and Norichika Kanie. "The Transformative Potential of the Sustainable Development Goals (SDGs)." International Environmental Agreements: Politics, Law and Economics 16 (2016), 393-396.

"Summary of the 2018 Meeting of the High-Level Political Forum on Sustainable Development." Earth Negotiations Bulletin (2018). Accessed 21 July 2018, http://enb.iisd .org/download/pdf/enb3345e.pdf.

Underdal, Arild, and Rakhyun E. Kim. "The Sustainable Development Goals and Multilateral Agreements." In Governing through Goals: Sustainable Development Goals as Governance Innovation, eds. Norichika Kanie and Frank Biermann (Cambridge: MIT Press, 2017), 241-258.

UN Conference on Environment and Development. The Rio Declaration on Environment and Development. (Rio de Janeiro, Brazil: UNEP, 1992). Accessed 3 February 2018, http://www.unesco.org/education/pdf/RIO_E.PDF.

UNEP (UN Environment Programme). 2016. "Global Environment Outlook 6 Regional Assessments.” Accessed 22 February 2017, https://www.unenvironment.org/resource s/global-environment-outlook-6-regional-assessments.

UNEP (UN Environment Programme). Role of Multilateral Environmental Agreements $(M E A s)$ in Achieving the Sustainable Development Goals (SDGs) (Nairobi, Kenya: UNEP, 2016).

UNEP (UN Environment Programme). Elaboration of options for enhancing synergies among biodiversity related conventions. (Nairobi, Kenya: UNEP, 2016). Accessed 6 March 2018, https://wedocs.unep.org/bitstream/handle/20.50o.11822/9967/elabor ations-options-enhancing-synergies.pdf?sequence $=1 \&$ isAllowed $=\mathrm{y}$.

UN General Assembly. Resolution A/RES/70/1, 21 October 2015.

UNEP-WCMC (UN Environment Programme-World Conservation Monitoring Centre). Mapping Multilateral Environmental Agreements to the Aichi Biodiversity Targets. (Cambridge:UNEP-WCMC, 2015). Accessed 23 April 2018, https://wedocs.unep .org/bitstream/handle/20.500.11822/11205/mapping-meas-aichi.pdf?sequence $=1 \&$ is Allowed $=\mathrm{y}$.

UNFCCC (UN Framework Convention on Climate Change). Kyoto Protocol. 1998. Accessed 13 June 2016, https://unfccc.int/resource/docs/convkp/kpeng.pdf.

UNFCCC (UN Framework Convention on Climate Change). Paris Agreement. 2015. Accessed 1o July 2016, https://unfccc.int/sites/default/files/english_paris _agreement.pdf. 
van Asselt, Harro, Francesco Sindico, and Michael A. Mehling. "Global Climate Change and the Fragmentation of International Law." Law and Policy 30 (4) (2008), 423-449.

Velázquez Gomar, José Octavio. "Environmental Policy Integration among Multilateral Environmental Agreements: The Case of Biodiversity." International Environmental Agreements: Politics, Law and Economics 16 (4) (2016), 525-541.

Voigt, Christina. Sustainable Development as a Principle of International Law: Resolving Conflicts between Climate Measures and WTO Law (Leiden: Martinus Nijhoff, 20o9). Water Convention. 2007. ECE/MP.WH/2/Add.2 EUR/o6/5069385/1/Add.2, MOP 1, Decision I/1. Accessed 19July 2016, https:/www.unece.org/fileadmin/DAM/env/doc uments/2007/wat/wh/ece.mp.wh.2_add_2.e.pdf.

Water Convention. 2015. INF.2015/2, MOP 7. Accessed 1 June 2017, https://www.unece .org/fileadmin/DAM/env/water/MOP7/Documents/Inf.2_HLS_programme_final2 .pdf.

Wiersema, Annecoos. "The New International Law-Makers? Conferences of the Parties to Multilateral Environmental Agreements." Michigan Journal of International Law 31 (1) (2009), 231-287.

Wilson, Maxwell C., and Jianguo Wu. "The Problems of Weak Sustainability and Associated Indicators." International Journal of Sustainable Development and WorldEcology 24 (1) (2017), 44-51.

Wolfrum, Rüdiger, and Nele Matz. Conflicts in International Environmental Law (Berlin: Springer 2011).

World Commission on Environment and Development. Our Common Future. (Oxford: Oxford University Press, 1987). 


\section{Appendix}

\section{Annex 1: List of Abbreviations}

AEWA Agreement on the Conservation of African-Eurasian Migratory Waterbirds

ASCOBANS Agreement on the Conservation of Small Cetaceans of the Baltic and North Seas

ASEAN Association of Southeast Asian Nations

CBD Convention on Biological Diversity

CITES Convention on International Trade in Endangered Species of Wild Fauna and Flora

CMS Convention on the Conservation of Migratory Species of Wild Animals

COP Conference of the Parties

EU European Union

EUROBATS Agreement on the Conservation of Populations of European Bats

IA Issue Area

ICZM Integrated Coastal Zone Management

IPPC International Plant Protection Convention

IS

Institutional Specialization

IUCN International Union for Conservation of Nature

LBS Land-Based Sources

MEA Multilateral Environmental Agreement

NS Non-Specialization

R Regime

SAICM The Strategic Approach to International Chemicals Management

SDGS Sustainable Development Goals

SPA/BD Specially Protected Areas and Biological Diversity

SPSS Statistical Package for the Social Sciences

UN United Nations

UNCCD United Nations Convention to Combat Desertification

UNCLOS United Nations Convention on the Law of the Sea

UNCSD United Nations conference on Sustainable Development

UNEP United Nations Environment Programme

UNFCCC United Nations Framework Convention on Climate Change

UNGA United Nations General Assembly

UNWC Convention on the Law of the Non-Navigational Uses of International Watercourses

WHC Convention Concerning the Protection of the World Cultural and Natural Heritage 
Annex 2: MEA s and Their Institutional Alignments and Affiliations

\begin{tabular}{|c|c|c|}
\hline MEA & Institutional specialization & Affiliation \\
\hline AIR CONVENTION & Atmosphere & UNECE \\
\hline MONTREAL PROTOCOL & Atmosphere & UNEP \\
\hline VIENNA CONVENTION & Atmosphere & UNEP \\
\hline AEWA & Biodiversity & UNEP \\
\hline CARTAGENA PROTOCOL & Biodiversity & UNEP \\
\hline CBD & Biodiversity & UNEP \\
\hline CITES & Biodiversity & UNEP \\
\hline CMS & Biodiversity & UNEP \\
\hline EUROBATS & Biodiversity & CMS/UNEP \\
\hline IPPC & Biodiversity & UN FAO \\
\hline LUSAKA AGREEMENT & Biodiversity & UNEP \\
\hline NAGOYA PROTOCOL & Biodiversity & UNEP \\
\hline PLANT TREATY & Biodiversity & UN FAO \\
\hline RAMSAR & Biodiversity & IUCN \\
\hline BAMAKO CONVENTION & Chemicals & UNEP \\
\hline BASEL & Chemicals & UNEP \\
\hline ROTTERDAM & Chemicals & UNEP \\
\hline SAICM & Chemicals & UNEP \\
\hline STOCKHOLM & Chemicals & UNEP \\
\hline KYOTO PROTOCOL & Climate & UNFCCC \\
\hline PARIS AGREEMENT & Climate & UNFCCC \\
\hline UNFCCC & Climate & UNFCCC \\
\hline UNCCD & Land & UNCCD \\
\hline ABIDJAN CONVENTION & Oceans & UNEP \\
\hline ANTIGUA CONVENTION & Oceans & UNEP \\
\hline ASCOBANS & Oceans & CMS/UNEP \\
\hline BARCELONA CONVENTION & Oceans & UNEP \\
\hline BARCELONA DUMPING PROTOCOL & Oceans & UNEP \\
\hline CARTAGENA CONVENTION & Oceans & UNEP \\
\hline HAZARDOUS WASTES PROTOCOL & Oceans & UNEP \\
\hline ICZM PROTOCOL & Oceans & UNEP \\
\hline LBS PROTOCOL & Oceans & UNEP \\
\hline NAIROBI CONVENTION & Oceans & UNEP \\
\hline OFFSHORE PROTOCOL & Oceans & UNEP \\
\hline PREVENTION AND EMERGENCY PROTOCOL & Oceans & UNEP \\
\hline SPA/BD PROTOCOL & Oceans & UNEP \\
\hline UNWC & Oceans & UNESCO \\
\hline WATER CONVENTION & Oceans & UNECE \\
\hline CARPATHIAN CONVENTION & No specific environmental field & $\begin{array}{l}\text { CARPATHIAN } \\
\text { CONVENTION }\end{array}$ \\
\hline ESPOO CONVENTION & No specific environmental field & UNECE \\
\hline INDUSTRIAL ACCIDENTS CONVENTION & No specific environmental field & UNECE \\
\hline KIEV PROTOCOL & No specific environmental field & UNECE \\
\hline
\end{tabular}


(cont.)

\begin{tabular}{lll}
\hline MEA & Institutional specialization & Affiliation \\
\hline KYIV PROTOCOL & No specific environmental field & UNECE \\
TEHRAN CONVENTION & No specific environmental field & TEHRAN \\
& & CONVENTION \\
WHC & No specific environmental field & WHC \\
AARHUS CONVENTION & No specific environmental field & UNECE \\
PROTOCOL ON WATER AND HEALTH & Social issue area & UNECE \\
\hline
\end{tabular}

\section{Annex 3: List of Multilateral Environmental Agreements and Their Full Titles}

Aarhus Convention

Abidjan Convention

Abidjan Convention

AEWA

Air Convention

Antigua Convention

Apia Convention

ASCOBANS

ASEAN Agreement

Bamako Convention

Barcelona Convention

Barcelona Dumping Protocol Protocol for the prevention of pollution of the Mediter-

ranean sea by dumping from ships and aircraft in decision-making and access to justice in environmental matters

The convention for the co-operation in the protection and development of the marine and coastal environment of the west and central African region

The convention for the co-operation in the protection and development of the marine and coastal environment of the west and central African region

Agreement on the conservation of African-Eurasian migratory waterbirds

Convention on long-range transboundary air pollution Convention for cooperation in the protection and sustainable development of the marine and coastal environment of the northeast pacific

Convention on conservation of nature in the south pacific Agreement on the conservation of small cetaceans of the Baltic and north seas

ASEAN agreement on transboundary haze pollution

Bamako convention on the ban on the import into Africa and the control of transboundary movement and management of hazardous wastes within Africa

Convention for the protection of the marine environment and the coastal region of the Mediterranean 
Basel Convention

Carpathian Convention

Cartagena Convention

Cartagena Protocol

CBD

CITES

CMS

Espoo Convention

EUROBATS
Basel convention on the control of transboundary movements of hazardous wastes and their disposal,

Framework convention on the protection and sustainable development of the Carpathians

Convention for the protection and development of the marine environment of the wider Caribbean region

Cartagena Protocol on Biosafety to the Convention on Biological Diversity

Convention on biological diversity

Convention on international trade in endangered species of wild fauna and flora

Convention on the conservation of migratory species of wild animals

Convention on environmental impact assessment in a transboundary context

Agreement on the conservation of populations of European bats

Hazardous Wastes Protocol Protocol on the prevention of pollution of the Mediterranean sea by transboundary movements of hazardous wastes and their disposal

ICZM Protocol Protocol to the Barcelona convention on integrated coastal zone management

Industrial Accidents Convention Convention on the transboundary effects of industrial accidents

IPPC International plant protection convention

IUCN International union for conservation of nature

Jeddah Convention Regional convention for the conservation of the red sea and of the gulf of Aden environment

Kiev Protocol Kyiv protocol on pollutant release and transfer registers to the convention on access to information, public participation in decision-making and access to justice in environmental matters

Kuwait Regional Convention Kuwait regional convention for co-operation on the protection of the marine environment from pollution

Kyiv Protocol Kyiv (strategic environmental assessment-SEA) protocol

LBS Protocol Protocol for the protection of the Mediterranean sea against pollution from land-based sources and activities

Lusaka Agreement The Lusaka agreement on co-operative enforcement operations directed at illegal trade in wild fauna and flora

Minamata Convention On Mercury Minamata convention on mercury 
Montreal Protocol

Nagoya Protocol

Nairobi Convention

Noumea Convention

Offshore Protocol

Plant Treaty

Prevention And Emergency Protocol Protocol concerning cooperation in combating pollution of the Mediterranean sea by oil and other harmful substances in cases of emergency

Ramsar Convention

Rotterdam Convention

SAICM

SPA/BD Protocol

Stockholm Convention

Tehran Convention

UNCCD

UNCLOS

UNCSD

UNFCCC

UNGA

UNWC

Vienna Convention

Water Convention

WHC

Montreal protocol on substances that deplete the ozone layer

Nagoya protocol

Convention for the protection, management and development of the marine and coastal environment of the eastern African region

The convention for the protection of natural resources and environment of the south pacific region

Protocol for the protection of the Mediterranean sea against pollution resulting from exploration and exploitation of the continental shelf and the seabed and its subsoil

International treaty on plant genetic resources for food and agriculture

Ramsar convention on wetlands of international importance especially as waterfowl habitat

Rotterdam convention

The strategic approach to international chemicals management

Protocol concerning specially protected areas and biological diversity in the Mediterranean

Stockholm convention on persistent organic pollutants

Framework convention for the protection of the marine environment of the Caspian sea

United nations convention to combat desertification

United nations convention on the law of the sea

United nations conference on sustainable development

United nations framework convention on climate change

United nations general assembly

Convention on the law of the non-navigational uses of international watercourses

Vienna convention for the protection of the ozone layer Convention on the protection and use of transboundary watercourses and international lakes

Convention concerning the protection of the world cultural and natural heritage 